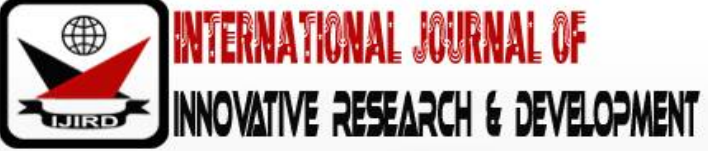

ISSN 2278 - 0211 (Online)

\section{African Economic Growth and Development: Lessons from the Association of Southeast Asian Nations (ASEAN)}

\author{
Austine Okere Ifeanyi \\ School of Political Science and Public Administration \\ Shandong University, Qingdao, China
}

\begin{abstract}
:
Various scholars have written extensively on issues bordering on development and economic integration within the African continent. Some of such studies focus on the colonial period, while others on post-colonial epochs. However, contemporary discussions have rightfully identified that Africa is on the verge of a new wave of imperialism which characterized trappings of both the colonial and post-colonial epochs. In spite of dictates of foreign policy, the current globalization set-up is doomed to ensure Africa plays second fiddle. Supporting this further are two key issues. Firstly the 'boom-burst' pattern of economic growth in Africa since the 1850s; and secondly the raise of new economic hegemon (s) who constantly seek for Africa's "cheap" primary resource. This paper is therefore a modest attempt to bring these issues into clearer perspective under the prism of economic integration. Subsisting on the Flying Geese (FG) theoretical framework and adopting both quantitative and descriptive methodology, the paper arrives at the conclusion that Africa stands to learn a lot from the Association of Southeast Asian Nations (ASEAN). The paper further concludes that since this arrangement (i.e. ASEAN) 'muscled' its way into the international system, institutional policy responses are needed to ensure Africa avoids the same wave of imperialism which characterized the $19^{\text {th }}$ and $20^{\text {th }}$ centuries.
\end{abstract}

Keywords: Africa, ASEAN, China, development, economic integration

\section{Introduction}

"There are no free meals in International Relations." Any student and enthusiast of International Studies would be familiar with this maxim as it demonstrates that constant interaction between and among nations-states are based on quid pro quo - give and take. With the world becoming smaller as a result of globalization -which has effectively brought nationstates closer than before- , actors within the international system are constantly devising means to remain relevant. Consequently, economic integration objectives when vigorously pursued could become a veritable means to ensure continual survival, sometimes to the detriment of other nations-states. For instance, under a globalization model, trade and investment could work to the advantage of developing a common market while free trade would ensure the removal of protective measures and tariffs, thereby putting indigenous entrepreneurs and cross-economic exchange into the fore. However, economic integration appears to be against the foreign policy objectives (which is mostly interest motivated) of powers which seek for weaker states, thereby penetrating and maintaining the view that inter-state relation should be on the basis of 'dog eat dog.'

But the problem with this general idea, as it concerns African countries, is their inability to maintain their own interest in this dog-eat-dog global world. Furthermore, since Africa appears to be at the bottom strata of international economic relations, this provides a precarious situation of being dependent on the dictates of some major players who have achieved sustained economic growth and development while seeking further domination of weaker states in the international system. Such situation is compounded by the following features: Firstly, African from independence remained an off-shoot of their erstwhile colonial powers and inter-relations where based on the dictates of either London or Paris. Secondly, the bi-polar nature of the international system (i.e. Western Bloc versus Eastern Bloc) during the Cold War further militated against African countries pursuing an interest-oriented economic relation policy which would be perceived as detrimental to hegemonic influence of either blocs. And lastly, in the face of multi-hegemonic influences on the international system and with the existence of emerging economies like China, Malaysia, Brazil, India, Russia, Singapore and many others African countries with the challenge of adopting a dynamic economic integration policy and model which could pitch these emerging economies against the 'old' ones just to ensure that her interest is maintained.

However, this appears to be a noble dream mainly because, till date Africa does not have a pragmatic ideological framework guiding her economic integration, rather she focus on regional economic integration arrangements which have since been punctured by inter-play of mistrust and miss-giving as well as colonial hand-overs. It can succinctly be said, that Africa's hopes for broad economic integration in the face of globalization and neo-colonialism is in a flux and a precarious situation. Africa appears to be pawns, subject to the demands of a dominant and exploitative international system where different group or hegemon seems to be benefiting at her expense. But some regions have been able to make significant 
progress in economic integration, giving them a higher bargaining chips or rather an upper hand. One of such is the Association of Southeast Asian Nations -ASEAN, which has first ensured the development of her member states, by achieving a complimenting economy through economic integration, while relating and pitching both China and other Western countries against themselves.

This study attempts to show how institutional changes in Africa is needed following the ASEAN economic integration model to avoid another exploitation of the African continent not only by China (whose continued demand for primary natural resources is unflinching) but other emerging economies which might want to follow the precedence laid by Britain, France, Germany, Portugal and Belgium in the 18th and $19^{\text {th }}$ Centuries. This works shows how if without timely institutional change, China (possibly ASEAN) members might start another wave of neo-colonialism with Africa suffering again.

\subsection{Theoretical Framework: Flying Geese Theory for International Economic Development}

There exist many theories which have attempted to explain the pattern of economic development over the years. Some of these theories have either adopted a regional specific approach to explaining how development and industrialization has progress over time. Among such analysis, some scholars have identified the economic progress in the East Asia and proffered explanation to this. Since the end of the Cold War in the early 1990s, the "Flying Geese" pattern of economic development gained credence in explaining the raising influence of East Asia in international economic relations. This so-called Flying Geese (FG) theory of economic development, originally expounded by a Japanese economist, Kaname Akamatsu of Hititsubashi University in Tokoyo, coined the phrase "Ganko-Keitai" in 1930s and was later translated as 'flying geese.' His purview has recently gained currency in academia. The FG is one of the three major doctrines of catch-up strategy, along with the "big push" and "import substitution or infant industry protection which development scholars have used in explaining economic improvements in Asia since the 20th Century." ${ }^{\text {th }}$ The FG theory is also more popularly cited in the media, especially when news about Asia's phenomenal economic growth is reported.

Given the fact that Akamatsu's original ideas were "diamonds in the rough" so to speak, the followers of Akamatsu's ideas have been polishing and elaborating on them. These ideas, he sketched out, centers on three separate though intertwined patterns of FG formation related to the process of industrial development in the Asian countries and the changing patterns of dynamic comparative advantage among them. Although the FG theory attempts to explain discussion from three basic areas namely: Import Substitution-Cum-Export Promotion; Structural Upgrading and Alignment of Countries at different Stages of Development; 2 it is the third aspect which appears to be cogent for the explanation of necessary integration in Asia and thus suitable for this discourse.

\subsection{An Alignment of Countries at Different Stages of Development}

A third FG pattern is the "alignment of nations along the different stages of development" 3 , a sequential position of the developing countries that are lined up behind the advanced nations so that the former can emulate, learn from and capitalize on growth stimuli/ externalities via economic interaction. As Akamatsu put it, "It is impossible to study the economic growth of the developing countries in modern times without considering the mutual interactions between these economies and those of the advanced countries." 4 In other words, the modern process of economic development can never be autonomous and self-sufficient but is necessarily with -and derived from-more advance countries.

The essence of growth lies in a process of climbing the ladder of comparative advantage from labour-intensive to gradually and increasingly more capital-and knowledge-intensive industries on the part of catching-up countries. ${ }^{5}$ This can be achieved through dynamic commercial interplays between advanced countries and developing ones. The countries across the world are at different stages of development, growing at different speeds of structural transformation. This constitutes a basis for dynamic comparative advantage, and the countries within a hierarchy of countries can interact with each other in a complementary and mutually augmenting way so they can benefit from the what Ozawa calls the "economies of hierarchical concatenation."6

It is this third pattern that has become most popularized and widely accepted among those scholars who make reference to the FG theory of economic development. A typical pattern cited usually is the FG formation of East Asian economies, a formation led by Japan and immediately followed by the NIEs (Newly Industrializing Economies) and then by the ASEAN, and more recently by China and Vietnam.

The general acceptance of this theory is evident, but, critique of the FG theory surrounds who is the "first geese". While Akamatsu and others like him pointed to Japan, other have considered the United States as the first or lead geese which first translated economic development towards Japan and then to other parts of Asia. To these critiques, they point that over the years, some NIEs (especially South Korea and Taiwan) have caught up with Japan in some heavy industries (e.g. steel) and in some high-tech sectors (e.g. electronics and telecommunications). ${ }^{7}$ Also, these scholars have contended that China's swift rise as a new workshop of the world has left the ASEAN in the dust thus the need for proper integration to work with this growing hegemon in Asia. Consequently, analysis provided by Okita shows that the ASEAN countries have adopted the third pattern of the FG model (mostly from the 1990s) in what he calls "regional transmission pattern"8 in a bid to not only reclaim its position on the FG model but to match China in her development and also give her a voice in international economics.

Impressively, since the last decades of the $20^{\text {th }}$ century this has been achieved with countries such as Indonesia, Singapore, Malaysia and Thailand who have taken leadership roles within the region and also matched the growth of China and Japan.

What lessons can Africa draw from this integration model as proffered by the FG theory and applied by ASEAN countries amidst emerging economies growth? Also, similarities between Africa and ASEAN countries abound, as they had also witnessed economic growth and growth reversals as well as colonialism and imperialism of the $19^{\text {th }}$ and $20^{\text {th }}$ century. 
Before discussing the potentials for adopting FG regional pattern for development in Africa, emphasis has to be made on the trends of economic growth in Africa since the 1950s for better understanding.

\subsection{Trends of Economic Growth in Africa Since 1950}

Africa has experienced high and continuous economic growth in the past decade, prompting analysts to argue that the continent has reached a turning point in its development history and is poised to play a more significant role in the global economy on the 21st century. According to Organization of Economic Cooperation and Development (OECD) Reports for 2012, it indicates that the average annual growth rate of real output in Africa increased from 1.8 per cent in 1980-1989 to 2.6 per cent in 1990-2000 and 5.3 per cent in the period of 2000-20109. The report further indicates that twelve countries within the continent had an average growth rate above the developing-country average of 6.1 per cent over the period 2000-2010, while two countries (Angola and Equatorial Guinea) had also achieved double-digit growth rates. Unlike in the 1980s and 1990s, Africa's average growth rate since the turn of the millennium has also been higher than the average growth rate of the world economy. Information from UNCTAD supporting this, showing that within 20002012, Africa's average annual growth rates was more than 2 per cent higher than those in Asia, Oceania, Eastern Asia and Asia ${ }^{10}$.

However, despite impressive growth rates, Africa has also witnessed significant slowdown in growth due to the global financial and economic crisis which rocked the world by 2008/2009. Nevertheless, Africa's average growth rate in the post global crisis period (from 2010) was still about 2 percentage points higher than that of the world economy. Such growth and "growth-reversal" further gives credence to the Boom-Bust theory which has characterized Africa's economic growth since the 1950s. Again, to demonstrate impressive trends which have characterize Africa's economic development some economic historians have attempted to draw similarities between these trends and those of pre-modernization Europe. ${ }^{11}$ such studies have posited that:

... Placing Africa's recent economic performance in a wider historical perspective highlights the fact that the continent's level of per capita income is comparable to pre-industrial Europe and that the institutional changes needed to ensure sustained economic growth have yet to take place. Growth reversals remain a serious threat to Africa's future prosperity, and therefore it is incumbent on policy-makers to focus a great deal more on the introduction of measures that can encourage development of robust institutions to maintain such growth. 12

Recent research on Africa's economic history has revised the narrative of unrelenting failure that characterized studies of African economies in the 1990s. A good example is the "Africa Dummy" literature inspired by Barro ${ }^{13}$ which sought to explain why African countries seemed to have lower-than expected rates of growth between 1960 and 1990. Further detailed research into African economic performance during that period confirms it is a story not of persistent failure, but rather of periods of growth followed by reversals which often erase any gains that were made during the growth spurt.

Succinctly put, since the 1950s, most African countries have followed a general pattern of growth and reversal. Two decades of relatively rapid growth from 1950 ended with the oil crisis of the 1970s and were followed by stagnation or negative growth in the 1980s and 1990s. However, the growth patterns of African countries also reflect the diversity of the continent as a whole. In a studies carried out by scholars like Jerven ${ }^{14}$ and Ndulu and O'Connell ${ }^{15}$ who published works filled with empirical evidence to support the above argument, their studies focused in four African countries (Kenya, Nigeria, Sierra Leone and South Africa) from 1950 through to 2008 and illustrated that despite overall economic growth patterns in Africa, different resource endowments and the unique political histories of each country have resulted in different growth paths, although none have achieved sustained economic growth (See Figure 1 below).

Drawing from their research, this work highlights growth patterns in these four African countries which can provide a rounded picture of the pattern of economic growth the continent from the 1950s. A snap shot of the growth and growth reversals which existed in Nigeria, as presented by these study shows that during the post-independence period, political conflict resulted in several growth reversals in Nigeria. Furthermore, in 1958 World Bank claimed that Nigeria's prospects for growth based on its agricultural exports (including palm oil, cocoa, groundnuts, cotton and rubber) were good but they depended on 'Nigerians' success in eliminating tribal or regional antagonism and maintaining high standards in public administration. ${ }^{16}$ However, the Biafran war of the late 1960s reversed earlier gains, and GDP per capita fell to below its 1950 level. ${ }^{17}$ The oil boom of the 1970s led once again to positive growth, but oil revenue has little lasting impact on per capita GDP, which declined in the 1980s and remained stagnant throughout the 1990s. Accordingly, some scholars have documented in their works that since 2000, oil production and expansion in agriculture and services have led to a period of renewed economic growth, but the country remains overwhelmingly dependent on its energy sector. 18

Another area to consider the economic trends in African deals with the investment requirements and investment levels. Unfortunately, most African countries have maintained that economic development would be achieved within the continent by attracting significant investment from external partners (mostly Europe, America and some Asian countries). 


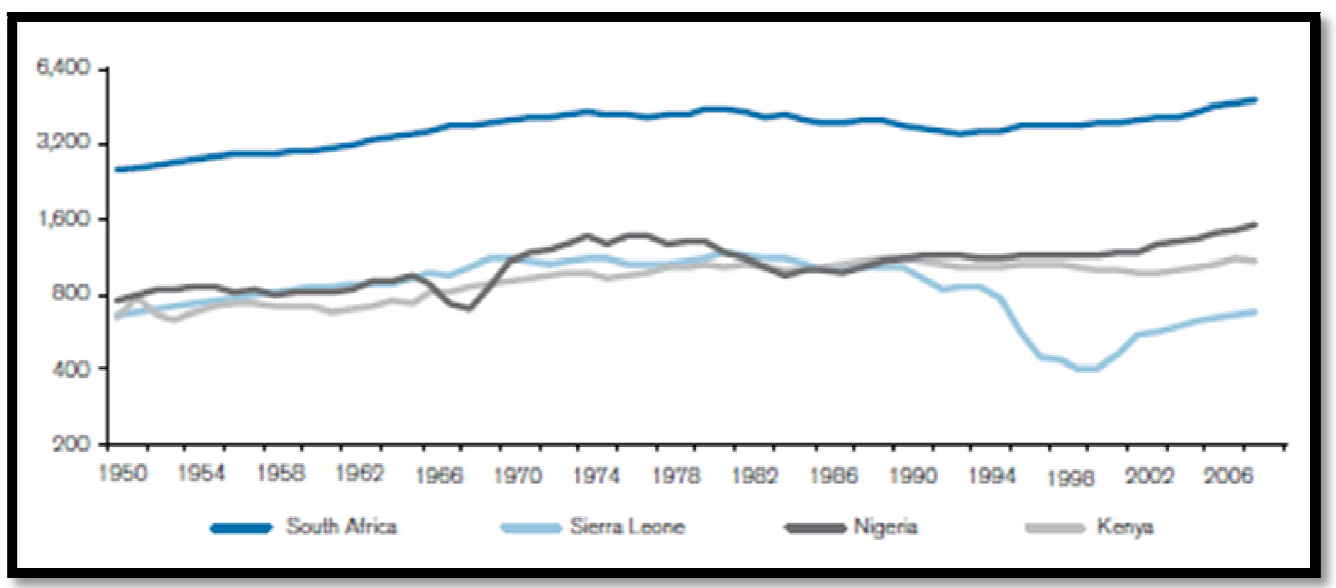

Figure 1: GDP Per Capita in South Africa, Nigeria, Kenya and Sierra Leone, 1950-2008 Source: Madison (2010)

Despite this, the United Nations Conference on Trade and Development -UNCTAD- Report for 2014 articulates that the trend for investment in Africa has not been sufficient to reduce poverty and instigate sustained economic growth. Moreover investment levels have further slowed as a result of growth and growth reversals which characterize Africa's development. The report believes:

Over the past two decades, the average investment rate in Africa has hovered around 18 per cent, which is below the 25 percent threshold, and so it is not surprising that the continent has not achieved the 7 per cent average growth rate required to make significant progress in reducing poverty. This fact suggests that the slow progress in realizing Africa's development goals over the past decades is in part a consequence of the fact that the continent has not made the level of investments required to achieve these goals... [Investment] in sub-Saharan Africa would need to reach $\$ 93$ billion per year in order to meet their development goals. But actual investment on the subcontinent is $\$ 45$ billion, implying a funding gap of about $\$ 50$ billion per year. ${ }^{19}$

African Governments have recognized the challenges posed by the current pattern of growth and have renewed their political commitment to economic transformation. At the continental level, economic transformation is one of the key priority issues in the draft strategic plan of the African Union entitled Agenda 2063. It is also one of the four priority issues identified by African countries in the African Common Position on the Post-2015 Development Agenda. The other issues are innovation and technology transfer, human development, and financing and partnerships. At the national level, many countries have also made economic transformation a key focus of their development agenda in the medium and long term. As such, country specific plans such as the Ethiopian Government Growth and Transformation Plan -aimed at boosting agricultural and industrial growth; Cote d'Ivoire Economic Emergence Strategy -aimed at making it an industrial economy by 2020; Uganda's vision 2040 and Lesotho's Vision 2020 which aims to give pride of place to industrial development in both countries respectively.

However, the UNCTAD report also contends apart from seeking foreign investment which pose a challenge to industrialization efforts, other key challenges which face countries in Africa is the need to understand the drivers of structural transformation in the development process. Thus, UNCTAD advises the identification of investment and technology lapses as key structural drivers for the required transformation..$^{20}$ Understanding this trend and the fact that there is an urgency to increase investment needed to meet the development gap in the continent (and to match the economic growth reversal), the 1990s saw an upsurge Bilateral Investment Treaties (BITs) between developing countries across the world. Traditionally, BITs have been signed mainly between developed and developing countries.

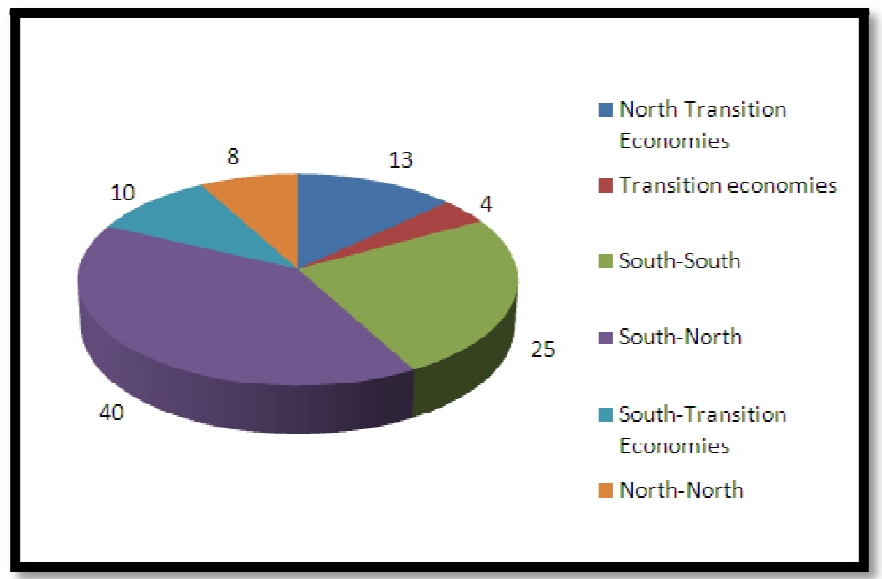

Figure 2: Global Distribution of Bits (As at 2004) Source: UNCTAD (Www.Unctad.Org/ Iia) 
This corresponds with their main objectives of promoting and protecting foreign investment, and with the roles of home and host countries initially being clearly separated between developed (home) and developing (host) countries. ${ }^{21}$ However, recently, the number of BITs between developing countries has grown significantly. According to UNCTAD, South-South BITs reached 451 in 2000 and 603 by the end of 2004. ${ }^{22}$. To date, South-South BITs account for 25 per cent if the BIT universe, involving 104 developing countries.

Africa since, 2000 has started looking into assistance from these emerging economies for investment and direction geared towards the path of economic growth. As such, many of these emerging countries continue to view Africa as an avenue to explore in bilateral agreements and development cooperation. Indices evaluated in 2004 reveals that among the top developing economies that have significant BITs and investments in Africa are those located in Asia and Latina America. Table 1 shows the extent of concluded BITs since 2004 and the countries which share most of these South-South BITs.

\begin{tabular}{|c|c|c|}
\hline Economy & Total & $\begin{array}{c}\text { With Developing Economies (Mostly } \\
\text { African Countries) }\end{array}$ \\
\hline China & 112 & 63 \\
\hline Korea (Republic of) & 90 & 48 \\
\hline Malaysia & 78 & 47 \\
\hline Indonesia & 58 & 33 \\
\hline Argentina & 58 & 29 \\
\hline Turkey & 71 & 28 \\
\hline Total & 467 & 248 \\
\hline \multicolumn{2}{|c|}{ Table 1: Top Developing Economies in Terms of South-South Bits, as at End of 2004 } \\
\multicolumn{2}{|c|}{ Source: UNCTAD (Www.Unctad.Org/ Iia) }
\end{tabular}

\subsection{Contemporary Economic Hegemon and Africa's Precarious Situation}

As indicated in the previous section, many developing economies concluded numerous BITs with African countries with the hope to boost their economic development and at the same time ensure economic returns and prestige for them within the larger international system. As such, many of them have reviewed the direction of their relationship and have understood the benefit of having Africa as a potential trading partner. Over the last two decades, some of these emerging economies have grown in terms of GDP and in sector specific areas. Among sectors which have seen significant improvements are the manufacturing sector and service sector. In all, this growth has contributed to a decline in poverty rates in these developing countries as well as an increase in the number of the middle class with their high demand for certain living standards. Some scholars believe it would be unjust to refer to all of them as developing countries but rather some as "emerging economies" or "emerging power." This phrase has been coined to describe a new group of states which has through a combination of economic prowess, diplomatic acumen and military might managed to move away from developing-country status to challenge the dominance of traditional mainly Western powers. ${ }^{23}$ In addition to this, such economies have been able to control population and at the same time improve health (with a decline in maternal and child mortality). Alden, after considering economic trends and interest of these emerging economies posited "China, India, and Brazil have at various times openly declared their economic interest in gaining access to Africa's resources and (to a lesser degree) markets. He further contends that since the last decade of the $20^{\text {th }}$ century, all these countries have used a combination of public and private sector means to achieve their aims. ${ }^{24}$ China is one of such countries.

Chinese history shows to us how a developing country can promote its economic growth by specializing human capital and combining natural resources with adequate export strategies for investments. Under what Xiao Bin calls the "Guangdong Model of Transition", Chinese economic emergence which was based on a government-led market and exportoriented economy since the 1980s succeeded in opening up China by combining local land advantages and cheap human resources for massive production for re-investment in other economies. Such investments in Africa especially through the machinations of the Forum for China-Africa Cooperation (FOCAC) established in 2002, has seen Africa as a region for ensuring significantly higher GDP growth rate. In the Nigerian context, the influx of affordable Chinese goods has increased the spending power of the average Nigerian and increased the profit margins for her retailers ${ }^{25}$. Understanding this model for development as developed by China and other East Asian countries, ${ }^{26}$ arguments have been put forward for every nation-state to first maximize her local resources to her advantage before engaging in this interest-driven competitive international system. Others argue for Africa, engaging with East Asian countries remains in Africa's best interest in order to maximize the benefits as against previous arrangements with the likes of USA, Britain and other trade partners.

Considering how China transformed from an "in-ward looking country" to a major contender in Africa's economic inter-state relations, Anas posits, since the Cold War ended in 1991, Africa-China relationship has been in the ascendant. He contends that Africans, believing that China can inspire and drive fresh hopes for their development, have been wittingly and unwittingly encouraging her deepening presence in the continent. ${ }^{27}$ Summing up his analysis, Anas like many other scholars who believe in the potentials for Sino-African relations argue "what Africa expects from China are assurances that she can play the role of benefactor and protector which the US and other Western countries have been playing for their client on the continent." 28 China since the Communist Revolution in 1949 have begun to cultivate relationship with Africa. One scholar in his work captured the strategies which Chinese policy makers have rightfully articulate since 1949 and sums it up that China's support for Africa extends even before independence covering broadly 
areas of political support for the national liberation struggles and economic cooperation through economic assistance to some African countries. ${ }^{29}$

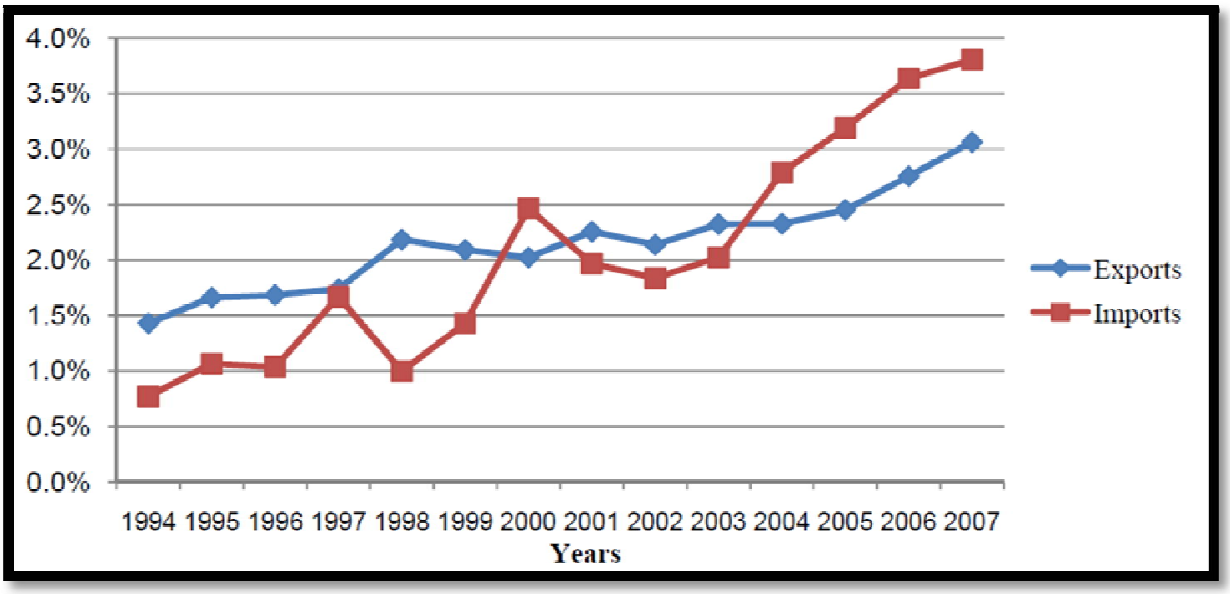

Figure 3: Africa's Share in Total Chinese Exports and Imports

Source: African Development Bank Working Paper: China's Trade and FDI in Africa

However, with the death of Chairman Mao and the economic reforms introduced in China (by 1978), China began to take a more strategic position in Africa. Since 2000, as a result of China's demands in Africa's material, China is now the number two oil consumer after the US and accounts for about 40 per cent of the growth of global energy demand for oil in the last five years. The Chinese get about 25 percent of their domestic energy needs from Africa, mostly from Sudan, Chad, Angola, Libya, Equatorial Guinea, Gabon and Algeria and this need has maintained about 9 per cent increase annually. In terms of trade (imports and exports) while European countries remain Africa's leading trade partners, Europe's share of Africa's export has fallen steadily. China's importance as an importer of African goods has also risen, while the share of the United States continues to increase and Europe's share declines. Africa's share of China's total exports and imports despite recent increases - remains less than 4 percent and is even smaller for manufactured goods. Trade with China is somewhat more important for Africa, representing almost 10 per cent of exports and imports. Obviously, it is impressive the trends of trade between China and Africa. However, it is important to consider these trends with historical perspectives.

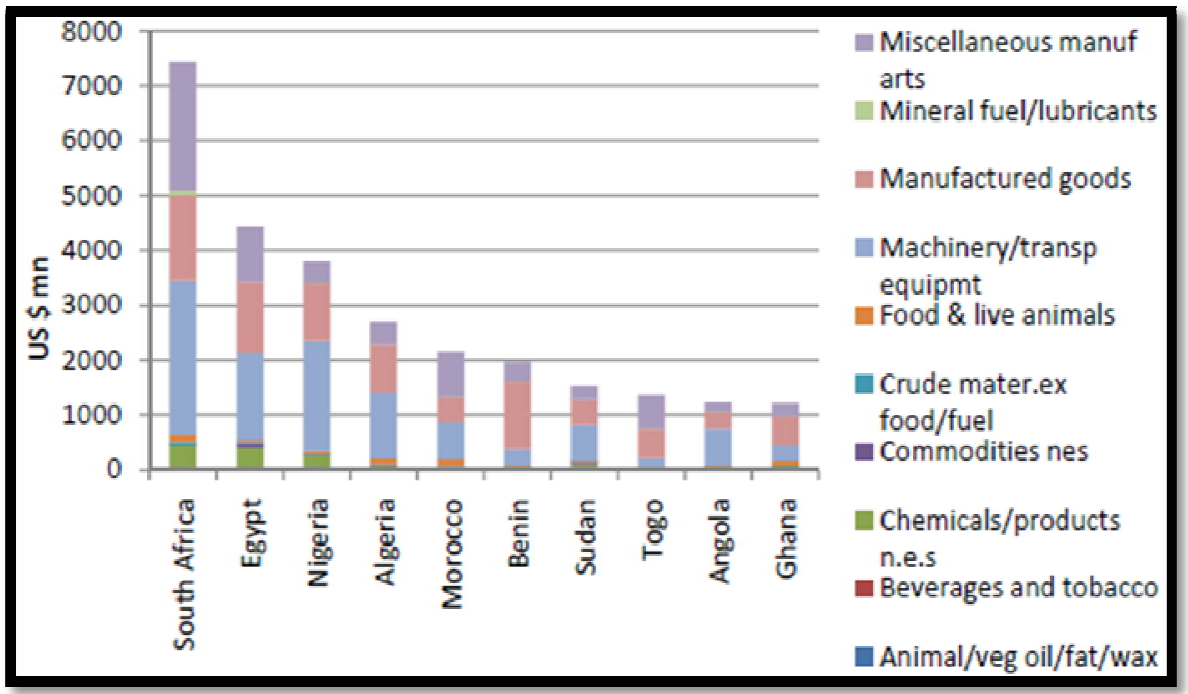

Figure 4: Key African Imports from China (By Country and by Product)

Source: African Development Bank Working Paper: China's Trade and FDI in Africa

Lessons of booming trade between Africa and other parts of the world (mostly with Western Europe and America) but without resulting benefits exists. The current researcher has in previous works examined this trend and drew striking similarity with the immediate post-independence period in Africa and China's current role in Africa ${ }^{30}$. Using the example of Nigeria, information showed that the key focus of trade was in primary produce significant to particular regions (or country) which was exploited by Britain, France and USA among others. Citing analysis provided by Obasi, ${ }^{31}$ the major sectors of the economy (in Nigeria) was dominated by foreign investments and domestic resources were exploited by foreign investors mainly for their own appropriation. In like manner, China (as well as other emerging economies) has improved trade relations with Africa in those areas she considers as important -mainly in the export of primary product or the "dumping" of its manufactured goods in Africa. Thus, to further argument this view, we recall the famous East Wind speech given by Chairman Mao, which clearly defines the path for China's relation with Africa. He said: 
It is my opinion that the international situation has now reached a new turning point. There are two winds in the world today, the East Wind and the West Wind. There is a Chinese saying 'Either the East Wind prevails over the West Wind or the West Wind prevails over the East Wind.' I believe it is characteristic of the situation today that the East Wind is prevailing over the West Wind...That is to say; the forces of socialism have become overwhelmingly superior to the forces of imperialism. ${ }^{32}$

Clearly, the track for competition had been laid during the 1950s and thus the race for the economic 'soul' of Africa. Currently, Nigeria just like the rest of Africa remains a destination for foreign investment both from East Asia and USA. While President Obama was rolling out the 7 billion USD 'Power Africa' investment plan, Japan and China are fiercely contesting for new markets in Africa. While Japan pledged over 32 billion USD aid to Africa, President Goodluck Jonathan flew to China to sign off on a 3 billion USD loan. Unfortunately, Africa might not always enjoy this position as policy makers not only in Nigeria but in Africa need to understand the need for an aggressive policy centered on preserving the interest of Africa within present scope of economic relations.

What remains perplexing is why Africa should think this current trend of economic relations with emerging economies (such as China) would yield impressive growth without learning from previous experience which eventually led to growth reversals which had characterized Africa's development. Since Africa, is the center stage for such economic battles, she needs to learn from the experience of other countries and regions that have been able to maintain positive economic relationships with both emerging countries and traditional economic power houses in the world. Thus ASEAN provides Africa with such an example which calls for emulation.

\section{Adopting the ASEAN Regional Integration Model}

\subsection{ASEAN from Past to Present:}

On the eve of ASEAN's creation in August, 1967, Southeast Asia was the center of world events. Aptly captured, Indonesia had recently been at war with Malaysia, trying to prevent the creation of Malaysia out of former British colonies. The Second Indochina War was raging, following the withdrawal of France in 1954 and the end of the First Indochina War that year. In Malaysia, a powerful communist insurgency was only defeated, while in Indonesia an army coup, launched along with rising left-leaning political parties, had unleashed massive communal bloodshed. The Cultural Revolution and China's support for several communist movements in Southeast Asia, as well as the region's fear of the United States abandoning its commitment to Southeast Asia, led the noncommunist countries in the region to form ASEAN. The original five members - Thailand, Malaysia, Singapore, Indonesia, and the Philippines -varied from military dictatorships to citystates to nascent democracies. ASEAN was founded with a limited charter, even compared to many other regional organizations. The goal was to preserve long term peace in Southeast Asia and, by unifying, (most recently) to balance the roles that outside powers, including United States, China and Japan played in Southeast Asia. 33

Furthermore, even though the Second Indochina War ended in the late 1980s, and ASEAN's mission evolved only marginally from its original goal, ASEAN made little effort to push for greater regional integration or trade liberalization. Despite China's economic opening in the late 1970s, China did not have formal relations with many Southeast Asian states and was a minor trading partner for the majority of the countries in the region by the late 1980s. Most ASEAN states were focused on building export-oriented manufacturing sectors that relied on low wages, Japanese capital and open Western markets. This strategy was extremely successful, at least for a time (in the early 1980s and early 1990s).

In the late $19^{\text {th }}$ century however, ASEAN developed economic muscle. After admitting new members who had been sidelined (as a result of Cold War politics); China at the same time launched a new "charm offensive" to diplomatically woo nations of Southeast Asia by proposing new trade deals, offering investment and training of Southeast Asian officials, and demonstrating an apparent willingness to put aside past territorial disputes and work within the ASEAN framework to solve confrontation in the South China Seas. ${ }^{34}$ China over the years has capitalized on the absence of Western countries ${ }^{35}$ and continued pushing policies to ensure that she work with the growing ASEAN influence in the region. China's officials privately and publicly noted that they had come to focus on Asian economic integration, rather than other issues as preoccupied by the West (mainly terrorism). This period also saw remarkable advances made by other emerging economies in the region at the same time -i.e. India, Japan and South Korea also built closer ties with ASEAN.

ASEAN leaders and officials since 2000, have begun to see the organization not only as relevant to Southeast Asia but also as the potential center for Asia-wide regional economic and, eventually, political integration. Former Singaporean diplomat Kishore Mahbubani - one of the most ardent ASEAN supporters - predicted a decrease in US power in Asia and its replacement by an Asia-centric regional order with ASEAN at its center. ${ }^{36}$ Other Southeast Asian leaders, such as Singapore's Lee Kuan Yew and the Philippines' Fidel Ramos, recognized that by dealing with China through a unified ASEAN, they could negotiate more favourable terms with China on trade, infrastructure, borders and other issues. ${ }^{37}$ Thus scholarship have reviewed China's current policy within Southeast Asia and posit that she has become more involved with ASEAN in the 21st century. Rightly, ASEAN has succeed (in economic terms) to coordinate and counter China's everincreasing massive influence which replaced the Cold War divides as relating with ASEAN is now the raison d'étre.

\subsection{Economic Integration}

The Association of Southeast Asian Nations (ASEAN) after understanding the complexity of its region in the growing dog-eat-dog global economy, developed an Economic Community Blueprint with the desire to "...transform ASEAN into a single market and production base; a highly competitive economic region with equitable economic development ... fully integrated into the global economy." 38 With this idea, since the first summit held Kuala Lumpur in 
December, 1997, these countries have worked in concert to ensure economic relations between its members and the 'Old' or 'New' economies is carried out within the ambit of "narrowing the development gap and accelerating the place of its member states in the global economy." 39 Little wonder Indonesia (which appears to be the country leading this pack) has been able to maintain an average economic growth on 7\% since 1997 making her the biggest economy in this region, while ensuring that other countries like Singapore, Thailand and Myanmar continue to record impressive economic growth. ${ }^{40}$ By assisting sister countries, the ASEAN region has tried to avoid the exploitative tendencies of other economic hegemon in the world, while also ensuring foreign direct investments.

ASEAN has been able to achieve this feat of economic integration on three fronts namely: Trade, Economics and Security. ${ }^{41}$ The focus of this paper would cover the only two (trade and economics) while leaving the political side of the integration. On the trade front, ASEAN's willingness (since 2000) to sign FTA's (Free Trade Agreements) crisscrossing the Asia-Pacific, even if those FTAs are slow to be implemented, has helped to situate Asia at the forefront of global trade liberalization. In addition, this web of Asian FTAs has helped spur trade liberalization in Asia with non-Asian members which have long favoured the WTO process; but which when they saw that ASEAN members were signing free-trade deals with other regional powers, they sensed the urgency to design its own regional free-trade agenda, which it did. In order words, ASEAN's openness to deals created a kind of "regional free-trade arms race." 42

Investigations into the development of FTAs within ASEAN further reveals that it has not only spurred emerging economies and major economies within the region to strive to negotiate free trade deals, but it has also inspired ASEAN members to discuss (more broadly) to FTAs between themselves. Evidence of this was cited by a Congressional Research Services which notes that as a result of these FTAs instigated by ASEAN, Singapore now has eighteen FTA in force with other nations. ${ }^{43}$ These FTAs have succeeded in giving ASEAN a broad outlook and the desire and prospects of an Asianwide-free trade area (pushed by more liberal ASEAN members -like Singapore). Such idea has been reviewed within the workings of the institutional document creating ASEAN to the creation of the Trans-Pacific Partnership (TPP), launched by Chile, Brunei, New Zealand and Singapore. Discussions are currently underway to include countries like Australia, México, Peru, New Zealand and even the USA.

On the economic front, besides reducing tariffs across the region, thereby potentially paving way for a regional free trade deal, ASEAN has also fostered other types of regional economic integration efforts. Specifically, following the Asian financial crisis of the late 1990s, when Asian nations relied on the International Monetary Fund (IMF) for bail-outs, several ASEAN members, as well as Japan and other Asian states, decided that Asia should amass its own reserves. The resulting Chiang Mai Initiative (CM), launched in May 2000, provided for a network of bilateral currency swaps between members of ASEAN +3 -the ASEAN countries plus China, Japan and South Korea. The CMI therefore created a reserves exchange pool to mitigate members' vulnerability to international capital inflow, speculation and contagion if any one member's currency collapsed. Since introduction, the initiative has since matured into a multilateral currency swap arrangement that includes even the U.S dollar while its membership has also expanded to booming economic centers like Hong Kong. Considering the significance of the CMI to economic integration in Southeast Asia, one scholar notes that the initiative has been symbolic in increasing the confidence of market participants in the liquidity of Asian banks. ${ }^{44}$

\subsection{China-ASEAN Relations}

A major development in China-ASEAN relations since the end of the Cold War is perhaps the growing economic interdependence between the two. Indeed, two-way trade has been growing at a rate of 20 per cent for the last decade and reached over $\$ 100$ billion in 2004 , a year ahead of a previously set target. ${ }^{45}$ It further registered a 23 percent increase in 2005, reaching \$130.4 billion. ASEAN member states have benefited from China's spectacular economic growth as the Asian giant's growing demands also generate economic benefits for the region as a whole. Over the years, China and ASEAN have institutionalized over forty-eight regular mechanisms to facilitate closer economic cooperation. The most prominent among them is the highest political mechanism -ASEAN +1, launched in 1997. Scholars have reviewed China's economic and political rationale for closely engaging with ASEAN. To most of them, such an arrangement could facilitate a more peaceful regional security environment which is very critical to China's ascendance to the international system and the world's economic order. Secondly, it addresses concerns in the region over China's growing power by more closely integrating ASEAN member states and China's need to be part of that integration process. ${ }^{46}$ Scholars thus believe, Beijing have over the years chosen to relate closely with ASEAN in order to address the perceived "China threat" in that area. Beijing, understanding the strategic importance of ASEAN in the region, has sought to promote the idea that both should complement, rather than compete in labour intensive manufacturing sectors and increase investment in each other countries.

The ASEAN nations have always viewed China with both suspicion and some cautious optimism. Their threat perceptions are influenced by history, geography and cultural factors. In the former sense, being small states vis-à-vis China; they have always harbored a suspicion of their giant northern neighbor for two reasons. One is the historical precedent, in particular Beijing's past support of the insurgent movements in their countries; the other is uncertainty about how China's preponderance and its growing weight in the post-Cold War era create additional concerns. ${ }^{47}$ Furthermore, ASEAN has been pragmatic enough to recognize the importance of engagement and hence adopted a strategy that aims at integrating China gradually into a regional web of economic interdependence, political dialogue, and security dialogue process. They also reject the strategy of containment as the best way to deal with rising China.

\subsection{Institutional Policy Response Needed for Africa Adopting the ASEAN Model}

Africa since the 1960s has created numerous institutions with the desire of achieving integration at so many levels. As such, the creation of these institutions has broadly covered areas such as economic, political, socio-cultural and 
for specific objectives. But for the fact these effort have not been able to spur significant economic advancement and a level playing field between African nations and the world, there becomes a need to review these institutions in tandem with contemporary desires and future objectives. Some of these institutions, although limited in function by challenges, have been renewed to meet the changes in the continent. For instance, the Organization of African Unity (OAU) was re-vigorated by the early 2000s into African Union (AU) to meet with the economic objectives of its founding fathers. ${ }^{48}$ Further calls have been made by some scholars towards the development of regional-base institutions styled after colonial financial and economic desires, which on the main succeed in promoting integration on a larger scale;49 but lessons in economic integration which the ASEAN model shows can attempt to lay a path way also for the African continent.

With the creation of institutions such as AU, ECOWAS, SADC, (but to mention a few), institutional framework for economic integration was already achieved in Africa. However, these institutions were created at a time when Chinese (and emerging economies) influence in Africa was partially felt. These institutions, particularly those with regional outlook, failed to successfully achieve economic integration in Africa. Furthermore, some of them became tools in the hands of imperial government resident in London, Paris or Washington. Again the internal divisions among member states of these institutions have further acted as deterrence to economic integration efforts. Thus, amidst the growing trends of globalization and the current volatile global economic system, Africa appears to be a pawn in the hands of the West (firstly) and now emerging economies led by China. Alli, in his remark and contribution towards the New Scramble for Africa describes particularly China's interest in Africa in terms of the "Push and Pull factors of China-Africa Relations" wherein, the focus (like in the past with erstwhile colonial countries) has been on natural primary commodities which Africa is blessed with..$^{50}$ For Africa to continue to allow this to happen remains antithetical to the principles of the Flying Geese (FG) model for economic development and growth. Consequently, while the likes of USA, Japan and even China and the emerging countries in ASEAN region could be regarded as part of the geese flight, Africa has not yet hatched; and would continue to wait if she does not work on institutions which would gear towards economic integration and eventual industrial take-off.

ASEAN, by developing her member state institutions and ability to take-off have forced China, and other emerging powers within and outside her region back to the negotiations table for well-rounded discussions from a position of advantage only achieved by regional integration. Some scholars even describe ASEAN's integration technique as the "Hedging Strategy" or "Low-intensity balancing" which seeks both the support of China, USA and other developed economies, but still maintaining a pride position which at the same time would benefit these countries to engage with ASEAN. ${ }^{51}$

The need to develop institutions can never be over emphasized. Acemoglu and Robinson, cited the reasons why countries in Africa have continued to fail over the years despite the numerous advantages. ${ }^{52}$ However, by adopting the ASEAN integration model first on a regional scale and then scaling it up to a continental level holds immense benefit for Africa. But first, developing national based industries in tandem with the FG model as postulated by Akamatsu and economies which compliments rather than are import or competitive oriented, this might be the best option for the continent more so even if China (and other economies) seek primary commodities (like crude oil), Africa can still gain.This would ensure Africa does nottradeviable aspects of her economic growth and development for short and medium gains. As such working and re-working on institutional mechanism and borrowing from the ASEAN experience to reposition such institutions such as the New Economic Partnership for Africa's Development (NEPAD), Africa's Development Bank -AfDB; Bank of African Settlements -BAS to work towards a broad-based integration of the African region.

On a final note, one lesson African policy makers should consider and take into perspective while discussing policy change is that, for ASEAN, discussions on major economic policies happened first at the regional integration institution level before this would trickle down to inter-state discussions. As such, China (and other developed economies), had to discuss first with ASEAN before attempting to strike significant economic relations with member states. Consequently, Africa should not allow the economic divide and rule syndrome which is currently in play to becloud her for seeing the bigger picture, which is economic integration.

\section{Conclusion}

African countries are hereby faced with an uphill task of understanding what role a well-developed economic integration policy can play in addressing her continual dependence on different economies of the world. For some, the inability to recognize the looking inward' step of economic development beclouds her ability to achieve an interest driven foreign policy. Compounded by the immediate desire to achieve economic development at all cost, Africa has struck numerous alliance (or dependence) with other countries without fair consideration of certain factors like how she could be at a better position of bargaining devoid of her dependency stance. Apart from these glaring inadequacies, the roles of regional-centered political and economic institutions have not succeeded in mitigating these problems. For instance, the Organization African Unity (establish since the 1960s and later renamed to African Union in 2000) have not been able to guide, monitor and ensure such economic relations is carried out with the interest of Africans at heart. Perhaps doing this might undermine member states' sovereignty, but considering factors like economic and political strength of individual countries, this might be a step in the right direction. Also, sub-regional economic and arrangements like Economic Community of West African States -ECOWAS; Economic Community of Central African States -CEEAC; East African Community -EAC and Southern African Development Community -SADC might have to share in this blame. Specifically, these organizations could play a vital role in devising an interest-driven integration outlook for different sub-regions; thus adopting the ASEAN stance. Countries like Nigeria, Ghana, South Africa, Uganda and Kenya capable of leading such process, have chosen to adopt an individualistic approach towards economic relations; of which such might prove precarious in the future. 
The aim would be to break away from dependency syndrome which besets Africa (mostly desperate economies like Nigeria) because yesterday it was dependence on the West -USA \& Britain, today it is the emerging economies of Asia (China, Japan etc.), tomorrow it might be those counties that started today to purse vibrant foreign economic policy to maximizing indigenous resources to make themselves relevant in the global economy.

\section{References}

i. $\quad$ S. Radelet and J. Sachs, "Asia’s Reemergence," Foreign Affairs 76 (6), 1997. pp 44-59

ii. K. Akamatsu, "A Historical Pattern of Economic Growth in Developing Countries," Developing Economies 1. 1962 pp.1-23

iii. K. Akamatsu, "A Theory of Unbalanced Growth in the World Economy." Welwirtschaftliches Archiv 86 (2), 1961 p. 215

iv. K. Akamatsu, "A Historical Pattern of Economic..."p. 1

v. P. Krugman, "Import Protection as Export Promotion: International Competition in the Presence of Oligopoly and Economies of Scale." In Kierzkowski, H. (ed.), Monopolistic Competition and International Trade, (Oxford: Clarendon Press, 1984). pp. 180-193

vi. T. Ozawa, "The Hidden Side of the 'Flying-Geese' Catch-up Model: Japan's Dirigiste Institutional Setup and a Deepening Financial Morass," Journal of Asian Economics. 12 p. 482

vii. P. Krugman, "Import Protection as Export Promotion: International ... p. 184

viii. S. Okita, "Pacifica Development and Its Implication for the World Economy" in Moley, J. (ed.) The Pacific Basin: New Challenges for China. (New York: The Academy of Political Science, 1997) p. 23

ix. $\quad$ OECD, 2012. African Economic Outlook 2012 (Paris: OECD Publishing) pp.12-16

x. UNCTAD, Economic Development in Africa: Report 2014, (New York: UN, 2014) p.12

xi. $\quad$ Maddison, A. (1995), Monitoring the World Economy, 1820 - 1992. (Paris, OECD)

xii. S. Broadberry and L. Gardner, Africa's Growth Prospects in A European Mirror: A Historical Perspective. The CAGE-Chatham House Series, No.5 February, 2013

xiii. R. Barro, "Economic Growth in a Cross Section of Countries." Quarterly Journal of Economics, 106 (2) 1991. pp. 4749

xiv. M. Jerven,. "African Growth Recurring: An Economic History Perspective on African Growth Episodes, 1690-2010," Economic History of Developing Regions, 25 (2) 2010.pp. 127-154.

xv. B. Ndulu and S. O'Connell, "Policy Plus: African Growth Performance, 1960-2000” in Ndulu, B., OÇonnell, Bates, R, Collier, P and Soludo, C. (eds), Political Economy of Economic Growth in Africa, 1960-2000. Volume I. (Cambridge: Cambridge University Press, 2008).p. 135

xvi. World Bank, The Economy of Nigeria. (Washington, DC: World Bank, 1958) p.11

xvii. M. Iyoha, and D. Orioaki., "Explaining African Economic Growth Performance: The Case of Nigeria" in Ndulu, B., O'Connell, S., Bates, R., Collier, P., and Soludo, C. (eds.), Political Economy of Economic Growth in Africa, 19602000, Volume I. (Cambridge: Cambridge University Press, 2008) p. 271

xviii. P. Collier and J. Gunning "Sacrificing the Future: Intertemporal Strategies and their Implications for Growth" in Ndulu, B., O'Connell, S., Bates, R., Collier, P., and Soludo, C. (eds.), Political Economy of Economic Growth in Africa, 1960-2000, Volume I. (Cambridge: Cambridge University Press, 2008) p. 49

xix. UNCTAD, Economic Development in Africa:...21

xx. UNCTAD, South-South Cooperation in International Investment Arrangements: UNCTAD Series on International Investment Policies for Development. (New York and Geneva, 2005: United Nations Publishers) p.18

xxi. UNCTAD, ...p.18

xxii. UNCTAD, ... p.19

xxiii. C. Alden, "Emerging Powers and Africa" London School of Economics Series on China's Economic Relations with Africa. Working Paper No 12. p.1

xxiv. C. Alden, ...p. 2

xxv. Data on foreign trade between Nigeria and China could be see here

http:/ / www.mongabay.com/ history/ nigeria/ nigeria-foreign_trade_foreign_trade_and_balance_of payments.html

xxvi. The argument is further sustained within the context that even USA and Britain developed inward first before they started expanding into the world. See (N. Crafts, "Patterns of Development in Nineteenth Century Europe and America," Oxford Economic Papers, 36. pp. 438-458

xxvii. E. Anas, "Zimbabwe Crisis: A Credibility Handicap for China's African Politics.” In UZU: Journal of History and International Studies. 3(1). 2012 p. 103

xxviii. E. Anas, "Zimbabwe Crisis..." p. 103

xxix. One of the lucid accounts of this was presented in A. Ogunsanwo, China's Policy in Africa 1958-71. (Cambridge: Cambridge University Press, 1971). Also, more on this was presented by C. Alden, "Leveraging the Dragon: Toward an Africa That Can Say No." in E-Africa, The Electronic Journal of Governance and Innovation. 3, 2005

xxx. A. Igwe and A. Okere, "Third World Dependency: The Nigerian Perspective." Journal of Arts and Contemporary Society. 5(2) pp. 67-86

xxxi. I. Obasi, "The Domestic Dimensions of the Nigeria Economy: 1960-1985." Nigeria's International Economic Relations: Dimensions of Dependence and Change. (Lagos: NIIA, 2005)

xxxii. Mao Tse-Tung speech, quoted in A. Ogunsanwo, China's Policy in Africa 1958-71. (Cambridge: Cambridge University Press, 1971)p. 15 
xxxiii. J. Kurlantzick, "ASEAN's Future and Asian Integration" Council on Foreign Relations Working Paper November, 2012.p.2

xxxiv. J. Kurlantzick, “ASEAN’s Future...” p.3

xxxv. In this case the researcher means the US. Most scholars contend that of all administration which had taken particular interest in Southeast Asia, the Bush (Senior) administration was by far the worst and was largely absent for the area. However, China and other emerging economies in the area -mainly Japan, India and South Korea exploited this during the early 2000s.

xxxvi. J. Kurlantzick, Charm Offensive: How China's Soft Power is Transforming the World. (New Haven: Yale University Press, 2007) p. 20

xxxvii. J. Kurlantzick, Charm Offensive: How China's...p.24

xxxviii. J. Kurlantzick, “ASEAN's Future..."p.5

xxxix. J. Kurlantzick, “ASEAN’s Future..."p. 18

xl. J. Kurlantzick, “ASEAN's Future...."p. 19

xli. J. Kurlantzick, Charm Offensive ... p. 35

xlii. J. Kurlantzick, "ASEAN's Future..."p. 47

xliii. E. Chanelett-Avery, "Singapore: Background and US Relations," Congressional Research Service Report (2010) p.19

xliv. For more on the CMI see w. Seok-Dong and A. Lene, "Regional Financial Cooperation in East Asia: The Chiang Mai Initiative and Beyond." Bulletin on Asia-Pacific Perspectives 2002/ 2003. (New York: United Nations, 2002) p. 55

xlv. See Xinhua, "China-ASEAN Trade Soaring." January 17, 2006, available at english.sina.com/ business/ 1/ 2006/ 0117/ 62228.html.

xlvi. Y.Jing-dong, China-ASEAN Relations: Perspectives, Prospects and Implications for US Interests. (New Jersey: Strategic Studies Institute Publications, 2006) p. 18

xlvii. Y.Jing-dong, China-ASEAN Relations: Perspectives, Prospects... p23

xlviii. For analysis and discussions on the economic integration ideals of the founding fathers of the OAU see S. Omoiya, "Pan-Africanism, the OAU and the African Union" in Ajayi, S. (ed) African Culture and Civilization (Ibadan: University of Ibadan Publishers, 2005) pp. 381 - 392

xlix. D. Chukwu, "Economic Integration of West Africa: Experience of the Colonial Period and other Climes," in Akinwumi, O. and Okpeh, O. (eds) Studies in Aspects of Economic History of Nigeria: Essays in Honour of Professor Yakubu Aboki Ochefu. (Abuja: Aboki Publishers, 2005) pp. 93 -109

1. W. Alli, "China-Africa Relations and the Increasing Competition for Access to Africa's Natural Resources, " in Eze, O. and Anigbo, C., (eds) New Scramble for Africa (Lagos: NIIA) pp.105-121

li. For more on these strategies which are still emerging as against the conventional idea of "Piggy-backing" or "Bandwagoning" see R. Sutter, China's Rise in Asia: Promises and Perils, (Lanham: Rowman \& Littlefield Publisers, 2005). D. Roy, "Southeast Asia and China: Balancing or Bandwagoning?" Contemporary Southeast Asia, 27(2) 2005, pp 305-322. N. Moranda, "ASEAN and the Rise of China: Engaging, While Fearing, an Emerging Regional Power," in Kokubun Ryosei and Wang Jisi, (eds)., The Rise of China and a Changing East Asian Order, (Tokoyo and New York: Japan Center for International Exchange, 2004) pp. 229-240.

lii. D. Acemoglu and J. Robinson, Why Nations Fail: The Origins of Power, Prosperity and Poverty, (New York: Crown Publishers, 2013) 